\title{
The winged bean (Psophocarpus palustris Desv.) in the treatment of kwashiorkor
}

\author{
BY K. ČERNÝ* AND HU'TTON A. ADDY \\ Princess Marie Louise Hospital, Accra, Ghana \\ (Received 21 February 1972-Accepted 22 fune 1972)
}

\begin{abstract}
1. A feeding trial with children suffering from kwashiorkor was conducted in which the winged bean (Psophocarpus palustris Desv.) was used as the major source of protein in the diet. 2. Seventy-two children who had been admitted to hospital with moderate or severe kwashiorkor were included in the study. The experimental diet, prepared from a mixture of two parts of the winged beans and three parts of maize flour, enriched with a small amount of skim milk, was given to twelve children with moderate and twenty-four children with severe kwashiorkor. Equal numbers of children with similar clinical, somatometric and biochemical measurements received a control diet in which most of the protein was provided by skim milk. Both groups of children had a supplementary meal of 'poto-poto' of negligible protein content, which supplied an extra $100-120 \mathrm{~kJ}$ per $\mathrm{kg}$ per $\mathrm{d}$. The diets were introduced after the children had overcome the most acute phase of the illness during which a routine diet based on skim milk and calcium caseinate had been given. Both diets supplied $4 \mathrm{~g}$ protein and $435 \mathrm{~kJ}$ per $\mathrm{kg}$ body-weight and were given to the children, on the average, for $30 \mathrm{~d}$.

3. The experimental diet was well accepted and tolerated, and all children made good clinical progress. The rates of gain in weight were slightly less in the experimental groups than in the children who received the control diet. Although the differences were not statistically significant, they were more marked in children whose weights were between $6 x$ and $75 \%$ of standard (classified as second degree kwashiorkor). With both diets, mean daily weight gains were significantly higher in children with severe kwashiorkor than in those with moderate kwashiorkor.

4. The increase in total serum protein and the decrease in the amino acid ratio determined 2 weeks after admission were nore marked in children given the control diet. At the end of the experimental period, however, the differences between the groups in these two measurements, as well as in values for haemoglobin concentration, protein fractions and the hydroxyproline index were no longer significant.

5. The high nutritive value and the pleasant, sweet taste, even in the raw state, are the main advantages of the winged bean. These should outweigh the disadvantage that its skin is tough and more difficult to remove than that of the soya bean.
\end{abstract}

The winged bean (Psophocarpus palustris Desv.) has been shown in a previous study by Cerný, Kordylas, Pospišil, Švábenský \& Zajic (I97I) to be of high nutritive quality. Analyses of the seeds showed a content of $37^{8} \mathrm{~g}$ protein $/ \mathrm{kg}, \mathrm{I} 8 \mathrm{I} \mathrm{g} \mathrm{fat} / \mathrm{kg}$, ${ }_{1} 3.9$ parts $/ 10^{6}$ thiamin and ${ }_{1} .8$ parts $/ 10^{6}$ riboflavin. The oil of the seeds contained $\mathrm{I} \cdot 259 \mathrm{~g}$ tocopherol $(\gamma+\beta)$ per $\mathrm{kg}$ and the contents of unsaturated fatty acids and of polyunsaturated essential fatty acids were satisfactory. The amino acid composition of the winged bean protein was very like that of the soya bean.

The protein efficiency ratio (PER) and net protein utilization (NPU) of the beans, determined with rats, compared well with those of the soya bean and were superior to those of the groundnut, which is at present the most important legume cultivated in Ghana. Mixtures of two parts of the winged bean and three parts of maize flour,

* Present address: Department of Tropical Medicine, Postgraduate Medical School, Ruská, 85 , Prague ro, Czechoslovakia. 
adjusted to either 100 or $160 \mathrm{~g}$ protein $/ \mathrm{kg}$, gave PER values similar to those of skim milk.

The study now described was undertaken to find out whether the winged bean could be safely used as a vegetable-protein substitute for milk in the treatment of proteinenergy malnutrition in Ghanaian children.

\section{EXPERIMENTAL}

\section{Subjects and methods}

Seventy-two children who had been admitted to the Princess Marie Louise Hospital in Accra, Ghana, with signs of moderate or severe kwashiorkor were included in the study. The degree of severity of kwashiorkor was assessed by both criteria described by Dean ( 1960 ), based on the extent of oedema and the general state of the patient, and those described by Gómez, Galván, Cravioto \& Frenk (I955), based on assessment of weight for age, using tables published by WHO (Jelliffe, r966). Children whose weights were between $6 \mathrm{I}$ and $75 \%$ of standard were classified as second degree kwashiorkor, and those with weights below $60 \%$ of standard as third degree kwashiorkor, measured at the time of maximum decline of the weight curve after subsidence of oedema.

The children were allocated to four groups, each containing equal numbers of boys and girls. Two of the groups, one of twelve children with second degree kwashiorkor and the other of twenty-four children with third degree kwashiorkor, were given the control diet with skim milk as the major source of protein. Another two groups, one of twelve children with second degree kwashiorkor and the other of twenty-four children with third degree kwashiorkor, were allocated to the experimental diet in which the greater part of the protein was derived from the winged bean. The ages of the children ranged between 12 and 48 months, most of them being between $I 8$ and 36 months.

Each child fed on the experimental diet had his counterpart fed on the control diet. The two children who formed a pair were of the same sex and were selected to have the minimum differences in age, birth weight (if known), body-weight and body length at the time of admission, circumference of head, chest and arm, type of kwashiorkor with respect to assessment by weight for age and extent of oedema, and similar results of biochemical determinants made shortly after admission. Since both diets under test were supplying $4 \mathrm{~g}$ protein but only $435 \mathrm{~kJ}$ per $\mathrm{kg}$ per $\mathrm{d}$, the children were given a fifth, largely carbohydrate, meal which provided I00-120 kJ per $\mathrm{kg}$ per $\mathrm{d}$. This was traditional Ghanaian meal of 'poto-poto', since some of the accompanying mothers were reluctant to feed their children exclusively with a strange and, in their opinion, not sufficiently nutritious diet so different from that given to other patients. As it was almost impossible to find simultaneously two newly admitted children who would fulfil all the requirements, the child who was to receive the experimental diet was always chosen first; later, at the earliest opportunity, the second child to form the pair was allocated to the control diet. Thus, although total admissions of children with proteinenergy malnutrition were about 500 per year it took 18 months to complete the whole study. 
Table $\mathrm{r}$. Composition of diets made up with water to give $\mathrm{I} l$ porridge

\begin{tabular}{|c|c|c|c|c|c|}
\hline \multicolumn{2}{|l|}{ Ingredient } & \multicolumn{4}{|c|}{ Content in porridge } \\
\hline Food & $\begin{array}{l}\text { Amount } \\
(\mathrm{g})\end{array}$ & $\begin{array}{l}\text { Protein } \\
\text { (g) }\end{array}$ & $\begin{array}{l}\text { Fat } \\
\text { (g) }\end{array}$ & $\begin{array}{c}\text { Carbohydrate } \\
\text { (g) }\end{array}$ & $\begin{array}{c}\text { Energy } \\
(\mathrm{kJ})\end{array}$ \\
\hline \multicolumn{6}{|c|}{ Experimental diet } \\
\hline Winged-bean flour* & 65 & 24 & 12 & I6 & 1122 \\
\hline Maize flour & 95 & 9 & 4 & 66 & 1406 \\
\hline Skim milk (dried) & 20 & 7 & Trace & 10 & 284 \\
\hline Groundnut oil & 22 & - & 22 & - & 829 \\
\hline Sucrose & 43 & - & - & 43 & 720 \\
\hline Totals & 245 & 40 & 38 & 135 & $436 I$ \\
\hline \multicolumn{6}{|c|}{ Control diet } \\
\hline Maize flour & 50 & 4 & 2 & 35 & 728 \\
\hline Skim milk (dried) & 100 & $3^{6}$ & I & 50 & 1478 \\
\hline Groundnut oil & 35 & - & 35 & - & I3I9 \\
\hline Sucrose & 50 & - & - & 50 & 836 \\
\hline Totals & 235 & $4^{\circ}$ & 38 & 135 & $436 I$ \\
\hline
\end{tabular}

The children were weighed on alternate days in the morning before they were fed. Supplements of vitamins, minerals and iron were offered to all children studied. Patients with signs of severe anaemia, folic acid deficiency, sickle-cell trait, or signs of any other accompanying disease were not included so that the nutritive value of the two diets would be the most important variable influencing the results.

Apart from routine laboratory tests, the following biochemical measurements were made in all children: haemoglobin concentration was estimated by the cyanmethaemoglobin method, the total serum proteins by the micro-biuret method, and the protein fractions by paper electrophoresis at $\mathrm{pH} 8.6$ using Whatman No. r filter-paper strips. The amino acid imbalance ratio in serum was measured as described by Whitehead (I964) and the hydroxyproline: creatinine index was determined according to Whitehead (1965). The protein fractions and the hydroxyproline index were estimated only on admission and at the end of the experimental period. All the remaining investigations were carried out also in the middle of the experiment, about the I 4 th day.

\section{Diets}

Treatment of kwashiorkor was begun in all children with a diet that has been in routine use in the hospital. It was prepared from dried skim milk, calcium caseinate (Casilan; Glaxo Laboratories Ltd), groundnut oil and sucrose, with added potassium chloride and magnesium hydroxide. The diet was offered during the acute phase of the illness until all oedema had subsided and until, after a temporary decline of the weight curve, the first gains in weight could be recorded. This period lasted, on the average, $3 \cdot 4( \pm 0 \cdot 7) \mathrm{d}$ in children with second degree kwashiorkor and $6 \cdot 2( \pm \mathrm{I} \cdot \mathrm{I}) \mathrm{d}$ in children with third degree kwashiorkor. Then either the experimental or the control diet was substituted gradually, that is over $3 \mathrm{~d}$, for the skim milk-Casilan mixture. The 
composition of these two diets is shown in Table $\mathbf{r}$. Both were designed to provide the same amounts of protein, fat and carbohydrate per 1 diet. 'The maize that was used in both diets was of the fermented type such as it is used in 'akasa' or 'koko', a favourite local dish for small children which, however, is usually served without milk. In our control diet skim milk provided $90 \%$ of the protein, and only $10 \%$ of the protein content was derived from maize. In the experimental diet only $17.5 \%$ of the protein content was supplied by skim milk, and $82.5 \%$ was of vegetable origin $(60 \%$ from the winged bean and $22.5 \%$ from maize).

The beans had to be soaked in water for $24 \mathrm{~h}$ before their tough skins could be removed. Usually, boiling the skinned seeds for $\mathrm{I} h$ was sufficient to make them soft enough to be mashed into a paste. When processing large amounts of the beans, they were steamed in an autoclave for $30 \mathrm{~min}$ at $100^{\circ}$, dried in a cabinet dryer at $55^{-} 60^{\circ}$ and ground into a flour. When used later in the kitchen of the hospital, this precooked winged-bean flour had to be boiled together with maize for $15 \mathrm{~min}$ before the other ingredients were added.

Both diets were offered in four meals daily, each of 200-250 $\mathrm{ml}$ porridge, according to the age, body-weight and appetite of the child. Although, the diets were offered ad $l i b$., the amounts actually consumed during the whole experimental period were, on the average, almost identical in all groups of children when related to their bodyweight. The mean daily intake per child recorded at the end of the experiment was $100 \mathrm{ml}$ porridge/ $\mathrm{kg}$ body-weight in each of the four respective groups, thus supplying $4 \mathrm{~g}$ protein and $435 \mathrm{~kJ} / \mathrm{kg}$ body-weight daily, irrespective of the type of diet and degree of kwashiorkor. As a fifth serving, the children were given a local, semi-solid dish, consisting most often of mashed plantain, cassava, yam, groundnut paste or palm-nut oil, vegetables and, occasionally, a small piece of fish or meat.

The experimental period began on the day when the first serving of the experimental or control diet was substituted for the skim milk-Casilan dict and it lasted for the same number of days for each child in a pair. The mean duration of the experiment was $30 \mathrm{~d}$.

\section{RESULTS}

The experimental diet was readily accepted and well tolerated. The children apparently liked the sweet, nutty taste of the winged beans that had the flavour, so familiar to them, of the fermented maize. Only one child, a boy aged 4 years, took the experimental diet reluctantly and, owing to poor weight gains, the diet had to be discontinued after ro d.

In most of the children given the experimental diet, diarrhoea ceased sooner, though the stools tended to be more bulky, than in the groups given the control diet. There were no gastro-intestinal upsets such as abdominal distention or excess flatus. Relapses of diarrhoea, which sometimes occur during treatment, were observed in six children of the control groups but in none in the experimental group.

'Two of the children, both with third degree kwashiorkor, died shortly after the study began. Another patient with second degree kwashiorkor developed measles and had to be transferred to the isolation ward at Korle-Bu Hospital. These three 
Table 2. Somatometric measurements at the time of admission to hospital and subsequent gains in weight in groups of children with kwashiorkor fed on the experimental and control diets

(Mean values and standard deviations: numbers of subjects in parentheses)

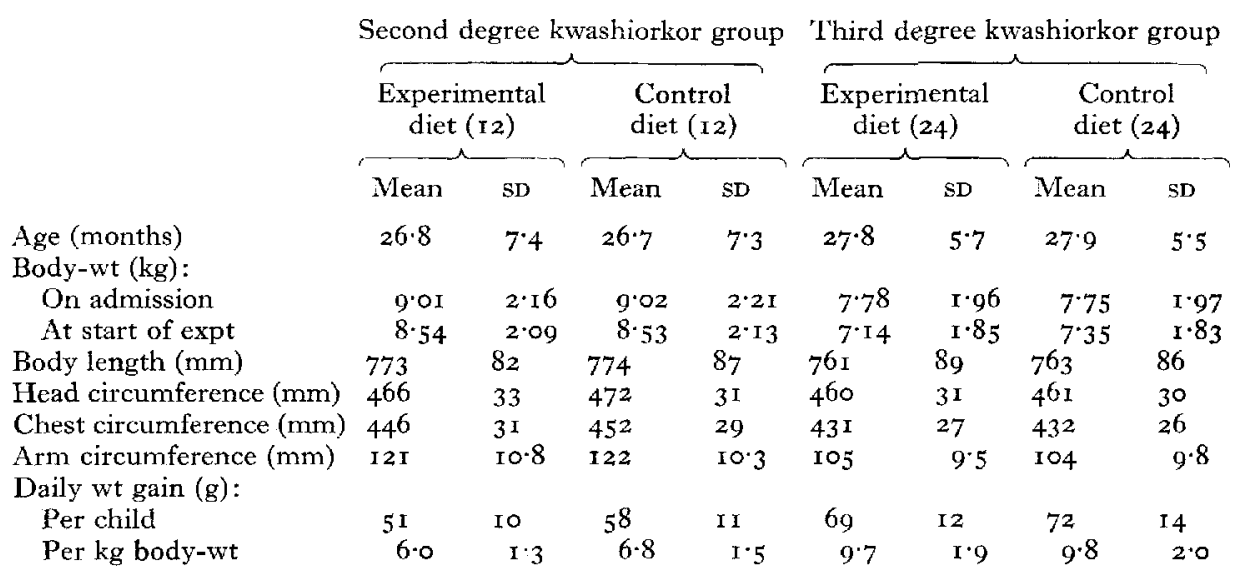

children and the boy who had refused the experimental diet were replaced by others to keep constant the number of pairs in each group.

The somatometric measurements on admission in the four groups of children with second and third degree kwashiorkor, and the mean daily weight gains of the children recorded at the end of the experimental period are summarized in Table 2.

On admission, the differences found between the experimental and the control groups of children, including children with second and third degree kwashiorkor, were not statistically significant.

When the mean daily weight gains attained by children fed on the two diets were compared, it was seen that the weight gains were slightly lower in the experimental groups, when expressed either as weight gained per child or as weight gained per kg body-weight. The difference, though not statistically significant, was more marked between the two groups of children with second degree kwashiorkor.

Significantly higher weight gains were observed, both on the experimental and the control diets, in children with third degree kwashiorkor than in children with second degree kwashiorkor $(P<0.0$ I for both diets $)$.

Table 3 gives the results of estimations of the haemoglobin concentration and of other biochemical investigations. Determinations made on admission showed no significant differences between the experimental and the control groups of children. Children with third degree kwashiorkor had a slightly lower concentration of haemoglobin and significantly lower levels of total proteins and albumin than children with second degree kwashiorkor $(P<O \cdot I)$. The amino acid imbalance ratio was also significantly higher $(P<0.0 \mathrm{I})$ and the hydroxyproline index significantly lower $(P<0.01)$ in children with third degree kwashiorkor.

After treatment, the gains in haemoglobin concentration and total serum proteins as well as the fall in the amino acid imbalance ratio determined after 2 weeks on the diet 
Table 3. Biochemical findings in children with kwashiorkor fed on the experimental and control diets $(A)$ at the beginning of the experiment, $(B)$ after $14 d$ and $(C)$ at the end of the experiment

(Mean values and standard deviations; numbers of subjects in parentheses)

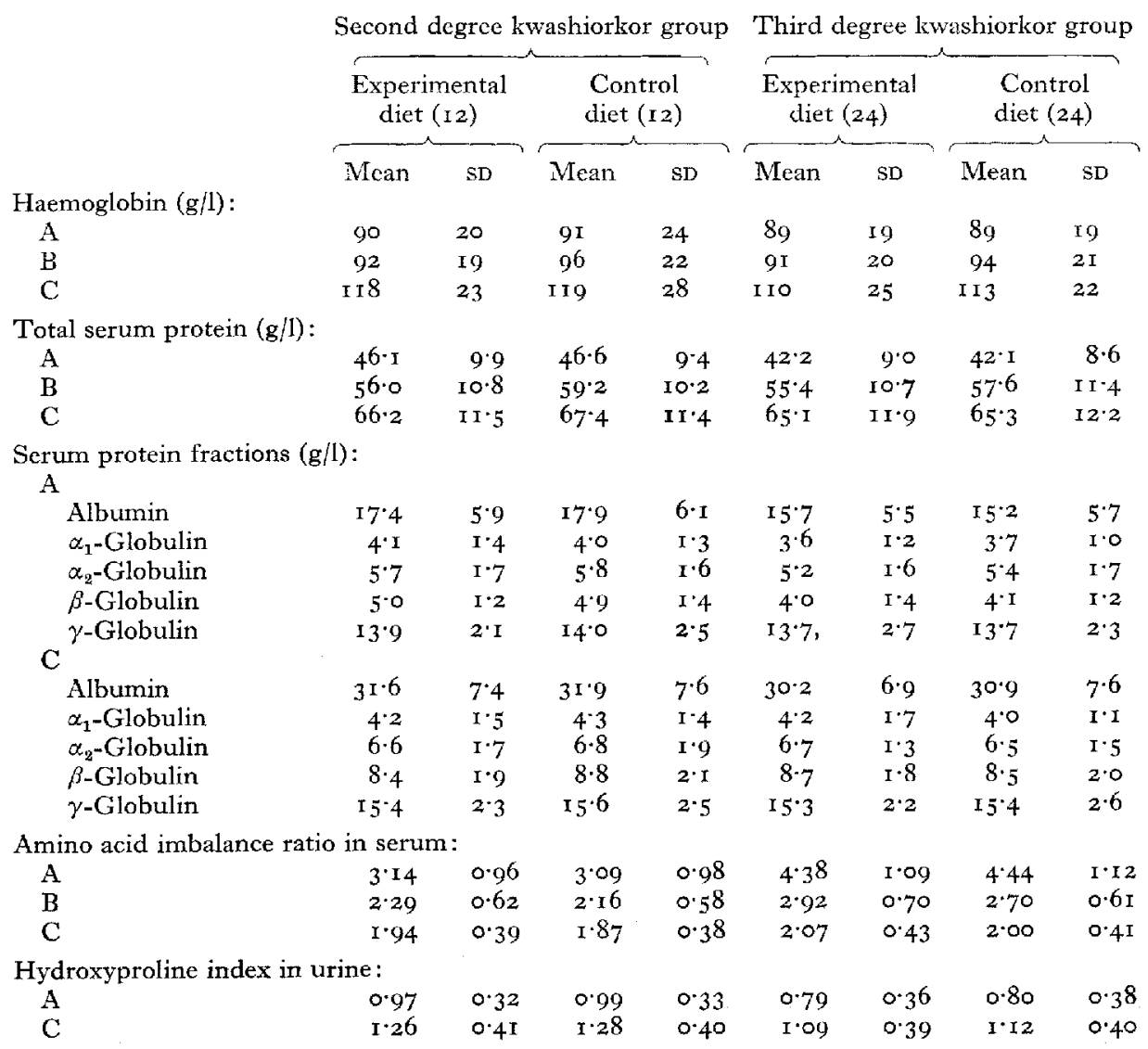

were more marked in the groups fed on the control diet, both in children with second degree and with third degree kwashiorkor. At the end of the experimental period, however, the differences between the experimental and the control groups for all measurements had become less pronounced and were not statistically significant.

\section{DISCUSSION}

Our results agree with those found in the numerous studies in which mixtures of vegetable proteins enriched with small amounts of animal protein were given to malnourished children as substitutes for milk. Soya beans, groundnuts, cottonseeds and chick pea have been used most extensively. The winged bean, however, has received little attention hitherto, although its contents of protein and fat are known to be similar to those of the soya bean (Nicholls, Sinclair \& Jelliffe, I96r). Fry (1965) recommends more extensive use of a similar variety (Psophocarpus tetragonolobus DC.) in the 
diet of Chinese children living in Hong Kong. The winged bean is also mentioned as a low-cost vegetable food rich in protein, suitable for use in recipes recommended by the World Health Organization (1968), for treatment of malnourished children in hospitals and health centres, with special reference to the Western Pacific. According to Dalziel (I955), the winged bean is indigenous in tropical West Africa, but there is no certain record of its cultivation, as in other parts of the tropics. In Ghana, it has been grown successfully for several seasons at the Agricultural Research Station (University of Ghana) in the forest area at Kade, where earlier attempts to grow the soya bean had been disappointing (Pospíšil \& Črný, i967).

Our study has shown that the winged bean is suitable for use as a milk substitute in treatment of children suffering from kwashiorkor. A mixture of two parts of the winged beans and three parts of maize flour, enriched with a small amount of skim milk, has given results similar to those achieved with a control diet in which $90 \%$ of the protein content was supplied by skim milk. Although in the first half of the experiment, the results were slightly better with the control diet, there was little difference between the results with two diets at the end of the experimental period.

When comparing the weight gains attained by the children with respect to the severity of kwashiorkor, it was interesting to find that, on both diets, children with third degree kwashiorkor not only gained wcight more rapidly but showed almost no signs of discrimination between the two dietary proteins. Some discrimination seemed to be marked, however, though not significantly, in children with second degree kwashiorkor. Whereas in the experimental group of children with third degree kwashiorkor the mean daily weight gain per $\mathrm{kg}$ body-weight was lower than in the corresponding control group by only $\mathrm{I} \cdot \mathrm{I} \%$, in the experimental group of children with second degree kawshiorkor it was lower by i $.8 \%$. A similar observation was made by Cerný, Hájková, Pechar, Vu Van Vinh, Rubín \& Zvolánková (rg68) when comparing the efficiency of a milk substitute based on soya-bean flour in feeding malnourished Vietnamese and well-nourished Czech infants. Although the mixture proved to have nutritive value similar to that of powdered whole milk in the treatment of malnourished Vietnamese infants and toddlers, it resulted in weight gains $30 \%$ lower than those of healthy Czech infants fed on milk.

There is little doubt that addition of a vegetable food rich in protein to the predominately carbohydrate diet of children in the low-income groups in the developing countries is most likely to bring about an improvement in the nutritional status of the children. However, it seems that, when estimating the nutritive value of the vegetableprotein mixture under test, the response obtained in malnourished children should be considered in relation to their nutritional status. This, of course, in no way alters the fact that growing the winged beans more intensively in selected areas of Ghana would help improve the nutritional status of the population, especially the young children. 


\section{REFERENCES}

Cerný, K., Hájková, S., Pechat, J., Vu Van Vinh, Rubín, A. \& Zvolánková, K. (I 968). F. trop. Pediat. I4,

Černý, K., Kordylas, M., Pospíšil, F., Svábenský, O. \& Zajíc, B. (1971). Br. F. Nutr. 26, 293.

Dalziel, J. M. (1955). The Useful Plants of West Tropical Africa 2nd reprint. London: Agents for Oversea Governments and Administration.

Dean, R. F. A. (1960). F. Pediat. 56, 675 .

Fry, P. C. (1965). F. trop. Pediat. ro, 100.

Gómez, F., Galván, R. R., Cravioto, J. \& Frenk, S. (1955). Adv. Pediat. 7, I3 I.

Jelliffe, D. B. ( 1 966). Monograph Ser. W.H.O. no. 53 .

Nicholls, L., Sinclair, H. M. \& Jelliffe, D. B. (editors) (196r). Tropical Nutrition and Dietetics $4^{\text {th }}$ ed.

London: Baillière, Tindall and Cox.

Pospíšil, F. \& Černý, K. ( 1967$)$. A. Rep. agric. Res. Stn, Kade, University of Ghana, Legon.

Whitehead, R. G. (I 964). Lancet i, 250.

Whitehead, R. G. (1 965). Lancet ii, 567.

World Health Organization (1968). F. trop. Pediat. 14, 149. 